\title{
CYP17A1 and Androgen-Receptor Expression in Prostate Carcinoma Tissues and Cancer Cell Lines
}

\author{
Alexandra Giatromanolaki ${ }^{a} \quad$ Virginia Fasoulaki $^{b} \quad$ Dimitra Kalamida $^{b} \quad$ Achilleas Mitrakas $^{b}$ \\ Christos Kakouratos $^{b} \quad$ Theodoros Lialiaris $^{c} \quad$ Michael I. Koukourakis $^{b}$ \\ a Department of Pathology; ' Department of Radiotherapy and Oncology; 'Department of Genetics, Medical School, Democritus University \\ of Thrace, Alexandroupolis, Greece
}

\author{
Key Words \\ Prostate cancer $\cdot \mathrm{CYP} 17 \mathrm{~A} 1 \cdot$ Androgen receptors • \\ Testosterone • Abiraterone
}

\begin{abstract}
Background: CYP17A1 is involved in the steroidogenesis of dehydroepiandrosterone and androstenedione. CYP17A is a target for the hormonal treatment of prostate cancer ( $P C a)$. Objectives: To investigate the role of CYP17A1 as a driver of PCa growth. Materials and Methods: We examined the expression of CYP17A1 and of androgen receptors (AR) in PCa specimens and in PCa cell lines. Results: CYP17A1 was strongly expressed in the cytoplasm of PCa cells (median $50 \%$ of cancer cells, range $0-100 \%$ ). The nuclear AR expression in cancer cells was directly related with CYP17A1 ( $p<$ $0.0001, r=0.51)$. The hormone dependent 22Rv1 cell line expressed the CYP17A1 and AR protein and mRNA, in contrast to the PC3 and DU145 cell lines ( $<0.0001)$. Testosterone and dexamethasone induced nuclear expression of $A R$ and this effect was abolished by abiraterone. CYP17A1 levels were not affected by the incubation with testosterone, while abiraterone significantly reduced its expression. Abiraterone reduced the growth rate and migration of testosterone stimulated 22Rv1 cells. Conclusions: CYP17A1 is strongly expressed in half about of human prostate carcinomas, imply-
\end{abstract}

\section{KARGER}

Fax +4161306 1234

E-Mail karger@karger.com

www.karger.com
(C) 2019 The Author(s)

Open access

This article is licensed under the Creative Commons AttributionNonCommercial-NoDerivatives 4.0 International License (CC BYNC-ND) (http://www.karger.com/Services/OpenAccessLicense) Usage and distribution for commercial purposes as well as any distribution of modified material requires written permission. ing an intracellular androgen synthesis by cancer cells. Abiraterone effectively blocked nuclear accumulation of AR and suppressed CYP17A1 expression. CYP17A1 may function as a biomarker to select the best hormonal anticancer therapy.

(c) 2019 The Author(s)

Published by S. Karger AG, Basel

\section{Introduction}

Prostate cancer $(\mathrm{PCa})$ is the second leading malignancy among men [1]. Localized disease is treated with prostatectomy or radiation therapy and the 5-year survival rates exceed $80 \%$. For metastatic and locally advanced disease, however, long-term survival is far lower. As PCa cells are androgen dependent, androgen deprivation therapy is a main therapy for patients with advanced metastatic disease [2]. Unfortunately, after months or years of hormonal therapy, castration-resistant PCa develops and disease progresses [3]. Bicalutamide is a widely used anti-androgen approved in combination with LH-RH agonists, in patients with metastatic disease. Inhibition of the biochemical conversion of cholesterol to androgens, occurring in the testicles and the adrenal glands, by blocking the hypophysial axis with LH-RH analogues are important. 


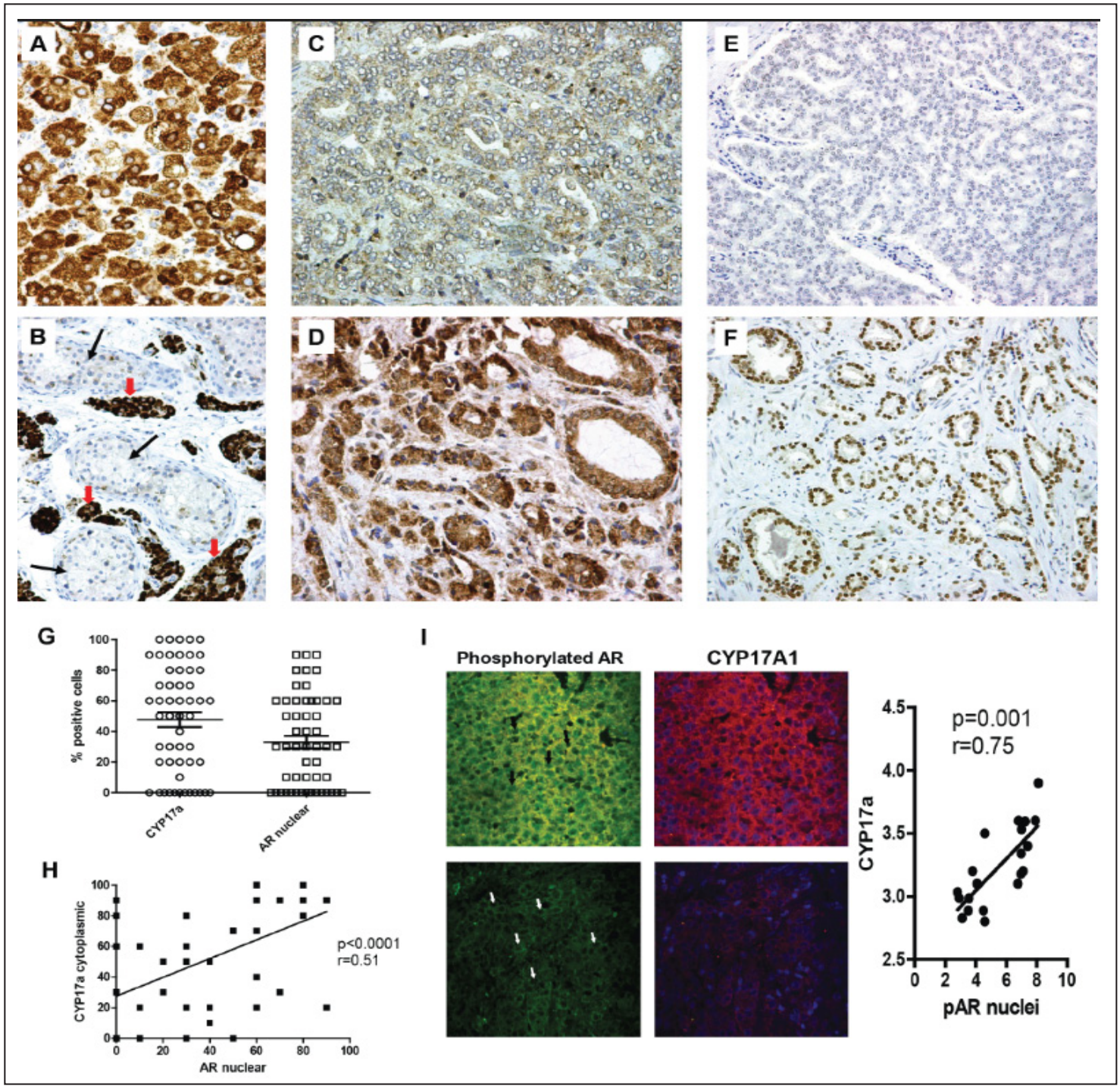

Fig. 1. Immunohistochemical and immunofluorescent detection of CYP17A1 and AR in human PCa tissues. A Strong expression of the CYP17A1 in adrenal secretory cells of zona reticularis; B Strong expression of the CYP17A1 in the Leydig testicular cells (thick arrows), whilst seminiferous tubules (spermatogenic and Sertoli cells) were completely negative (thin arrows); C PCa with lack of CYP17A1 expression; D PCa with strong CYP17A1 expression; E PCa with lack of AR expression; F PCa with extensive nuclear AR expression; G Distribution of the percentage of cells with strong CYP17A expression or nuclear AR expression, among prostate carcinomas examined; H Linear regression analysis of CYP17A versus nuclear AR expression; I Immunofluorescent confocal microscopy shows that nuclear expression of phosphorylated AR (active form) (black arrows) is accompanied by strong CYP17A1 expression, whilst lack of AR expression (white arrows) goes along with poor CYP17A1 expression. Linear regression analysis of immunofluorescent intensity confirms a strong statistically significant direct association of phosphorylated AR and CYP17A1 $(p=0.001, r=0.75)$.

Several mechanisms have been postulated to switch the initially hormone sensitive PCa cell phenotype to hormone resistant [4]. These include the up-regulation of genes encoding steroidogenic enzymes (i.e. CYP17A1 and CYP19A) or overexpression of androgen receptors (AR) by cancer cells. Amplifications and variations of the AR gene may lead to an enhanced gene copy number and to an increased AR activity, respectively. Mutations 
in ligand-binding domain of AR can also allow activation of the AR by many other ligands, such as progesterone, estrogen and adrenal androgens $[5,6]$ allowing cells to escape the suppressive activity of bicalutamide.

Here we investigated the expression of CYP17A1 enzyme in a series of PCa tissue from patients treated with prostatectomy and in PCa cell lines. We are aimed to provide evidence that a subset of prostate tumors possess enzyme mechanisms allowing the in-situ production of testosterone and thus the auto-activation of the AR pathway.

\section{Materials and Methods}

Formalin-fixed paraffin-embedded material in 53 tissue samples from $\mathrm{PCa}$ patients treated with radical prostatectomy were retrieved from the archives of our pathology department. All tumors were adenocarcinomas of the prostate and their distribution according to the Gleason score was as follows: Gleason 5-6 ( $\mathrm{n}=$ $23), 7(n=14)$ and $8-10(n=16)$. The median age of patients was 68 years (range $53-85$ years). Total $14 / 53$ patients $(26.4 \%$ ) had extraprostatic invasion (T3 stage), while node involvement was confirmed in only $2 / 53$ (3.7\%) cases. The study has been approved by the local ethics and research committee.

\section{Immunohistochemistry}

The rabbit monoclonal anti-CYP17A1 antibody, raised against a synthetic peptide within human cytochrome P450 17A1 aa 100-200 (ab125022, Abcam, Cambridge, UK; http://www.abcam. com/cytochrome-p450-17a1-antibody-epr6293-ab125022.html) was used at a dilution of 1:50. The mouse monoclonal anti-AR antibody clone AR441 (DAKO, Denmark; http://www.finels.com/ product/up_files/M3562.pdf) used worldwide in the standard clinical practice was used to detect the AR expression in the nuclei of cancer cells at a dilution of 1:50. Assessment of Ki-67 proliferation marker (MIB-1 antibody; DAKO, Glostrup, Denmark) was also performed.

Immunohistochemistry was performed on formalin-fixed paraffin-embedded tissue sections of $3 \mu \mathrm{m}$ that were placed on positively charged slides. Following deparaffinization and rehydration, heat-induced epitope retrieval process was performed in a microwave oven using Dako EnVision FLEX Target Retrieval Solution $(\mathrm{pH}$ 6.0). Tissue sections were incubated with anti-CYP17A1 primary antibody (overnight at $4 \mathrm{oC}$ ) and with the anti-AR antibody at room temperature (RT) for $60 \mathrm{~min}$. Following primary antibody incubation, buffer washing of the slides was performed $2 \times 6$ min and EnVision FLEX peroxidase-blocking reagent was applied for $10 \mathrm{~min}$ in order to block endogenous peroxidase of the tissues. Slides were washed with buffer solution $2 \times 6 \mathrm{~min}$ and then incubated with EnVision FLEX+ Rabbit (for anti-CYP17A1) or Mouse (for anti-AR) Linker for $15 \mathrm{~min}$ in order to amplify the signal. Tissue sections were buffer washed $2 \times 6$ min and Dako EnVision FLEX HRP detection reagent was applied for $30 \mathrm{~min}$. It consists of a dextran backbone onto which a large number of peroxidase molecules and secondary antibody molecules have been coupled. Buffer washing was then carried out $3 \times 6 \mathrm{~min}$ and EnVision FLEX DAB+ Chromogen was applied to the sections for $6 \mathrm{~min}$. The final step of the procedure involved buffer washing $2 \times 6$ min, counterstaining with hematoxylin QS (Vector H-3404), dehydration through graded ethanol solutions as well as xylene and mounting of tissue sections in synthetic resin.

Omission of the primary antibody was used as a negative control. Validation of the antibodies was further performed by examining the expression signal of the antibodies in tissues reported to express or not the mRNAs in the Human Protein Atlas (https:// www.proteinatlas.org/ENSG00000148795-CYP17A1/tissue and https://www.proteinatlas.org/ENSG00000169083-AR/tissue). Thus, immunohistochemical signal obtained in adrenal tissue (reported as positive for CYP17A1), testis (reported as positive for $\mathrm{AR}$ ) were performed in parallel with the immunostaining of $\mathrm{PCa}$ tissues. Indeed, this was verified as shown in figure 1A, B. Strong expression of the CYP17A1 was noted in adrenal secretory cells of zona reticularis and the Leydig testicular cells. Seminiferous tubules (spermatogenic and Sertoli cells) were completely negative, so that testicular tissue was used as a double positive and negative control for subsequent immunohistochemical analysis of prostate carcinoma tissues.

The percentage of cancer cells expressing nuclear AR and MIB-1 or with strong cytoplasmic expression of CYP17A1 was assessed in all available fields $(\times 200)$ and the mean value was used to score each case. Values higher than the median value were used to group cases as of high protein expression.

\section{Cell Lines}

The 22Rv1 androgen dependent cell line was purchased from ATCC (https://www.lgcstandards-atcc.org/Products/All/CRL2505.aspx). The PC3 and DU145 cell lines that have low dependent on androgens were purchased from the CLS Germany (http:// clsgmbh.de/p1699_PC-3.html and http://clsgmbh.de/p708_DU145.html). Additionally, a certificate of authentication of cell lines was granted by the Eurofins Forensik, Germany.

Cells were cultured under aseptic conditions using DMEM basal medium (Biosera LM-D1102) supplemented with $10 \%$ fetal bovine serum (FB-1000/500, Biosera), 100 units/ml penicillin and $100 \mu \mathrm{g} / \mathrm{ml}$ streptomycin (15140-122, Gibco, MD, USA). Cells were maintained at standard conditions $\left(37^{\circ} \mathrm{C}, 5 \% \mathrm{CO}_{2}\right)$ in humidified atmosphere and were used upon reaching 70-90\% confluence.

\section{Immunofluorescence Protocols and Image Analysis}

Ten tissue samples considered with negative AR expression in immunohistochemistry and 10 with high nuclear expression were selected and stained with an immunofluorescence staining protocol for both phospho-AR and CYP17A1 proteins. Anti-CYP17A1 rabbit monoclonal and anti-phospho-AR mouse monoclonal primary antibodies (1:200 and 1:100 respectively, Abcam, UK) were incubated for $1 \mathrm{~h}$ at RT. The slides were then washed in PBS $\mathrm{pH}$ 7.4, incubated with the appropriate CF488 and CF564 secondary antibody (1:250; Biotium, CA, USA) and the DNA was counterstained with Hoechst $33342(1 \mu \mathrm{g} / \mathrm{ml}$; Sigma-Aldrich) for $30 \mathrm{~min}$ at RT, followed by PBS washes. After final washes with PBS coverslips were mounted on the top of the samples using homemade Mowiol mounting medium.

For cell immunofluorescence staining, cells were grown on No. 1.5 glass coverslips, fixed in $3.7 \%$ paraformaldehyde/PBS $\mathrm{pH} 7.4$ for $20 \mathrm{~min}$ at $37^{\circ} \mathrm{C}$ and then permeabilized in PBS $/ 0.1 \%$ (v/v) Triton X-100 pH 7.4 for 5 min at RT. In addition, cells were 
Table 1. Sequence of primers used for the detection of androgen receptor (AR), CYP17A1 and actin- $\beta$ (ACTB) mRNA

\begin{tabular}{ll}
\hline Primer name & Primer sequence $\left(5^{\prime} 3^{\prime}\right.$ ) forward/reverse \\
\hline AR & CAGCCTATTGCGAGAGAGCTG \\
& GAAAGGATCTTGGGCACTTGC \\
CYP17A1 & GCATCATAGACAACCTGAGCAA \\
& GGGTTTGTTGGGGAAATC \\
ACTB & CCAACCGCGAGAAGATGA \\
& CCAGAGGCGTACAGGGATAG \\
\hline
\end{tabular}

blocked in PBS/5\% w/v BSA pH 7.4 for 20 min and stained with various primary antibodies: anti-phospho-AR mouse monoclonal (1:200; Abcam, UK) and anti-CYP17A1 rabbit monoclonal (1:200; Abcam, UK) for $1 \mathrm{~h}$ at RT. Cells were washed in PBS pH 7.4, incubated with appropriate CF 488 and 564 secondary antibodies at RT and DNA was counter-stained with Hoechst 33342 ( $1 \mu \mathrm{g} / \mathrm{ml}$; Sigma-Aldrich). After final washes, coverslips were mounted in homemade Mowiol mounting medium. Imaging was performed on a customized Andor Revolution Spinning Disk Confocal System built around a stand (IX81; Olympus) with 20x and 60x lens and a digital camera (Andor iXon+885) (CIBIT Facility, MBG-DUTH). Image acquisition was performed by using Andor IQ 2 software. Optical sections were recorded every $0.3 \mu \mathrm{m}$. All confocal microscopy images presented in this work are 2D maximum intensity projections of z-stack images (ImageJ $1.47 \mathrm{v}, \mathrm{Na}-$ tional Institute of Health, USA).

Image intensity analysis for the obtained data sets has been performed using ImageJ $1.47 \mathrm{v}$ (National Institute of Health, USA) software.

\section{Western Blot}

Cell lines were cultured in 6-well plates. After 24 hours incubation with Abiraterone Acetate, cells were treated with or without Testosterone at concentration $10 \mathrm{nmol} / \mathrm{Lt}$, for 2 hours before cell lysis. Whole cell lysates were prepared in a lysis buffer, consisting of HEPES $10 \mathrm{mmol} / \mathrm{l}, \mathrm{KCl} 60 \mathrm{mmol} / \mathrm{l}$, EDTA $1 \mathrm{mmol} / \mathrm{l}, 0.1 \%$ (v/v) Triton at $\mathrm{pH} 7.6$, protease and phosphatase inhibitors. Cells were incubated with this lysis buffer for $15 \mathrm{~min}$ at $4{ }^{\circ} \mathrm{C}$, following scraping and storage at $-20^{\circ} \mathrm{C}$. For nucleus and cytoplasm fractionation, cells were incubated with this lysis buffer for $15 \mathrm{~min}$ at $4^{\circ} \mathrm{C}$, following scraping, homogenization and centrifugation for $5 \mathrm{~min}$ at 3,000 rpm. Supernatants were collected as they included cytoplasmic proteins and pellets were suspended in a new lysis buffer with Tris- $\mathrm{HCl} 25 \mathrm{mmol} / \mathrm{l}$ at $\mathrm{pH} 7.4$ and sucrose $0.25 \mathrm{~mol} / \mathrm{l}$ and centrifuged for $5 \mathrm{~min}$ at $3,000 \mathrm{rpm}$, at $4^{\circ} \mathrm{C}$. Supernatants were discarded and pellets that included nuclei proteins were resuspended in the above sucrose-based lysis buffer and were stored at $-20^{\circ} \mathrm{C}$. Bicinchoninic acid protein estimation was performed to determine the total protein concentration of our samples. To denature the samples, each cell lysate was mixed with $1 \times$ Laemmli buffer and boiled at $100^{\circ} \mathrm{C}$ for $5 \mathrm{~min}$, at $4^{\circ} \mathrm{C}$.

Proteins of each lysate were resolved by $10 \%$ SDS gels and transferred to PVDF membranes that had primarily been activated with methanol for 1 min and rinsed with distilled water and transfer buffer before preparing the stack. After transfer electrophoresis, membranes blocking was performed with $5 \%$ w/v nonfat dry milk and $1 \times$ TBST for $1 \mathrm{~h}$ at RT. Blocking stage was followed with primary antibody incubation at $4{ }^{\circ} \mathrm{C}$ overnight with anticytochrome P450 17A1 antibody [EPR6293] (ab125022) from Abcam at $1 / 1000$ dilution in $1 \% \mathrm{BSA} / \mathrm{TBST}$ and anti-androgen receptor antibody [AR 441] (ab9474) from Abcam at 1/500 dilution in $1 \%$ BSA/TBST. The membranes were then incubated for $1.5 \mathrm{~h}$ at RT with the secondary antibodies, goat anti-rabbit IgG (H\&L)-HRP conjugate \#1706515, BIORAD at 1/3000 dilution in $1 \%$ BSA/TBST and goat anti-mouse IgG (H\&L)-HRP conjugate \#1706516, BIORAD at 1/2000 dilution in 1\% BSA/TBST. Each membrane was then stripped with mild stripping buffer for 10 min, blocked with $5 \% \mathrm{w} / \mathrm{v}$ nonfat dry milk and $1 \times$ TBST for $1 \mathrm{~h}$ at RT and rehybridized for $1 \mathrm{~h}$ at RT with the mouse Ab beta-actin (AC-15) [NB600-501], Novus Biologicals at 1/3000 dilution in $1 \% \mathrm{BSA}$ /TBST and the Lamin-B1 nuclear protein (ab133741; Abcam, UK) at 1/2000 dilution. The detection method utilized the ChemiDoc $^{\mathrm{TM}}$ MP System and the Clarity ${ }^{\mathrm{TM}}$ and Clarity Max ${ }^{\mathrm{TM}}$ Western ECL Blotting Substrates. Imaging quantification was performed with ImageJ software.

\section{RT-PCR Analysis}

High purity cultured cell total RNA kit, (AN0145, Canvax, Spain) was used for RNA extraction. A total of $2 \times 10^{6}$ cells were collected after trypsinization for $5 \mathrm{~min}$ at $37^{\circ} \mathrm{C}$ and centrifugation for $5 \mathrm{~min}$ at $500 \mathrm{rpm}$. For RNA harvesting, the cells pellet resuspended in Lysis buffer and $3.5 \mu \mathrm{l} \beta$-mercaptoethanol. Then the steps of this kit were followed in order to achieve a high yield of RNA. The sample concentrations were measured using the NanoDrop 2000c (Thermo Scientific, USA) and RNA samples were stored at $-80^{\circ} \mathrm{C}$.

Total 500 ng of RNA and the PrimerScript ${ }^{\mathrm{TM}}$ RT Reagent Kit (RR037A, TAKARA, USA) was used for cDNA synthesis. A reaction of $10 \mu \mathrm{l}$, which contains $200 \mathrm{ng}$ of RNA, $1 \times$ PrimeScript Buffer, 25 pmol of Oligo (dT's), 50 pmol of random hexamers and $0.5 \mu \mathrm{l}$ of PrimeScript RT Enzyme Mix I, was prepared. The suggested conditions for reverse transcription we re used: $15 \mathrm{~min}$ at $37^{\circ} \mathrm{C}$ for reverse transcription to be performed followed by an inactivation of reverse transcriptase step at $85^{\circ} \mathrm{C}$ for $5 \mathrm{~s}$. The cDNA samples were stored at $-20^{\circ} \mathrm{C}$.

In this study, the expression levels of the genes were measured using real-time quantitative PCR and KAPA SYBR ${ }^{\circledR}$ FAST qPCR kit optimized for LightCycler ${ }^{\circledR} 480$ (KK4611, KAPA Biosystems, USA) were used. The reaction of $20 \mu$ was prepared adding $1 \times$ of KAPA SYBR ${ }^{\circledR}$ FAST qPCR Master Mix $(2 \times)$ Universal, $200 \mathrm{nM}$ of forward primer, $200 \mathrm{nM}$ of reverse primer and $10 \mathrm{ng}$ of cDNA. The suggested cycle conditions were used: 1 cycle at $95^{\circ} \mathrm{C}$ for 3 min and 40 cycles at $95^{\circ} \mathrm{C}$ for $10 \mathrm{~s}, 56^{\circ} \mathrm{C}$ for $20 \mathrm{~s}$ and $72^{\circ} \mathrm{C}$ at 1 s. All reaction conditions were performed on Roche LightCycler ${ }^{\circledR}$ $480 \mathrm{II}$ in triplicates. The primer sets used, which were designed by the Roche primer design tool, are presented in Table 1.

The relative changes in transcriptional levels of all genes between control and different conditions were calculated using the comparative $\mathrm{Ct}$ method ( $\left.2^{\text {-ddCt }}\right)$ as the efficiencies of the target genes and reference gene are approximately equal near to $100 \%$. ACTB was used as a reference gene for the normalization of the results.

\section{Proliferation Experiments}

For proliferation experiments, cell growth was measured with Alamar Blue assay. A 96-well plate with 250 cells per well in triplicate for each condition was prepared using standard methods. Cells were incubated for $24 \mathrm{~h}$ for cell attachment in plate 


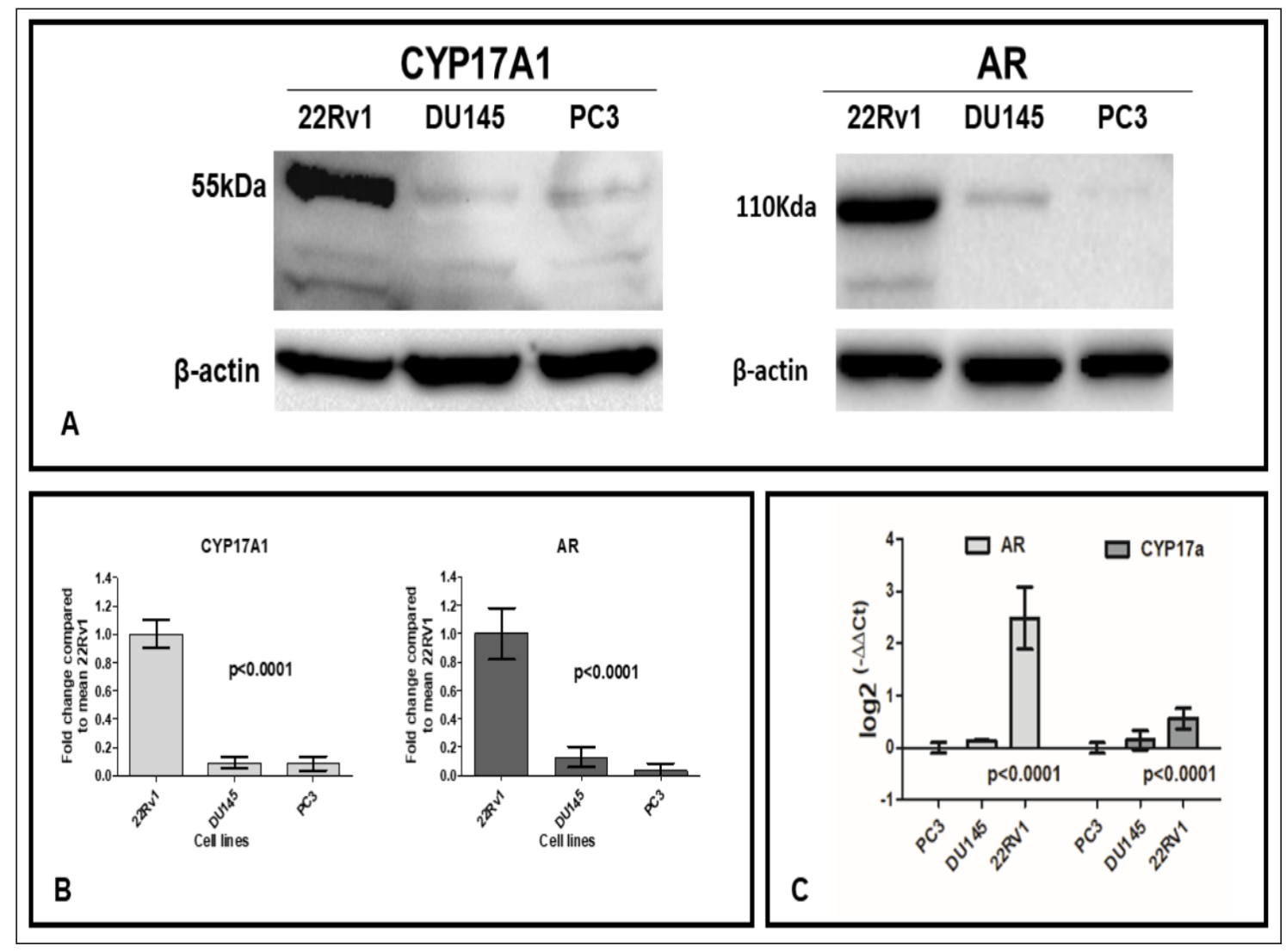

Fig. 2. Western blot of CYP17A1 and AR proteins. A 22Rv1 hormone dependent and the PC3 and DU145 hormone independent PCa cell lines; B Western blot band densitometry; C mRNA levels of AR and CYP17A1 gene expression in the 3 PCa cell lines.

surface. Abiraterone (Janssen Pharmaceutica NV) was dissolved in DMSO at $250 \mathrm{mM}$ concentration and tested at concentrations $10 \mu \mathrm{M} / 1$, although higher concentrations of 50 up to $1,000 \mu \mathrm{M}$ were also tested. Testosterone (Alpha-Pharma Healthcare, Chandivali, Mumbai, India) tested at $10 \mathrm{nM}$. To provide an estimate of the correlation of the above concentrations with plasma levels of patients, the normal levels of testosterone in men is around 20 $\mathrm{nM}$ [7], while the AUC concentration in the plasma of abiraterone in patients receiving $1,000 \mathrm{mg}$ daily (recommended dose) ranged 1.4-14.4 $\mu \mathrm{M}$ depending on dietary factors [8]. Correlations, however, between in vitro and in vivo concentrations of drugs are difficult to interpret, taking also into account that plasma levels do not predict for tissue concentrations. Drugs were present throughout the days of proliferation monitoring. Measurements were obtained every 2 days for 6 days, using a FLUOstar Omega microplate reader (BMG Labtech $\mathrm{GmbH}$, Germany).

\section{Migration Assay}

For cancer cells lines, migration assays of treated (testosterone $10 \mathrm{nM}+$ abiraterone $10 \mu \mathrm{M}$ ) and control cells (only testosterone $10 \mathrm{nM}$ ), an IBIDI Single Culture-Insert (IBIDI GmbH, Germany) in a $\mu$-Dish $35 \mathrm{~mm}$ was used. This migration monitoring system consists of 2 reservoirs separated by a $500 \mu \mathrm{m}$ thick wall. Equal numbers of cells $\left(7 \times 10^{5}\right.$ cells $\left./ \mathrm{ml}\right)$ were added into the 2 reservoirs of the same insert and incubated at $37^{\circ} \mathrm{C} / 5 \% \mathrm{CO}_{2}$. After $24 \mathrm{~h}$ the insert was removed with caution creating a gap of 500 $\mu \mathrm{m}$. Mitomycin C (Kyowa Kirin) treatment with $5 \mu \mathrm{g} / \mathrm{ml}$ for $3 \mathrm{~h}$ before the insert was removed, has been used in order to inhibit cell proliferation, a potential confusing variable. The $\mu$-Dish 35 $\mathrm{mm}$ has been finally filled with complete DMEM growth medium and the migration was monitored by bright-field microscopy at specific time points. Images were obtained every $6 \mathrm{~h}$ following the creation of the gap. The images were analyzed using TScratch software, developed by the Koumoutsakos group (CSE Lab), at ETH Zurich, the percentage of cells free area was calculated and plotted using the GraphPad Prism 5.01 statistical package (GraphPad Software Inc., USA).

\section{Statistical Analysis}

Statistical analysis and graph presentation was performed by using the GraphPad Prism 5.0 (GraphPad Software Inc., USA). The unpaired two-tailed t-test and the Wilcoxon matched pairs test were used to compare groups with continuous variable data as appropriate. A p-value of $<0.05$ was used for significance. 


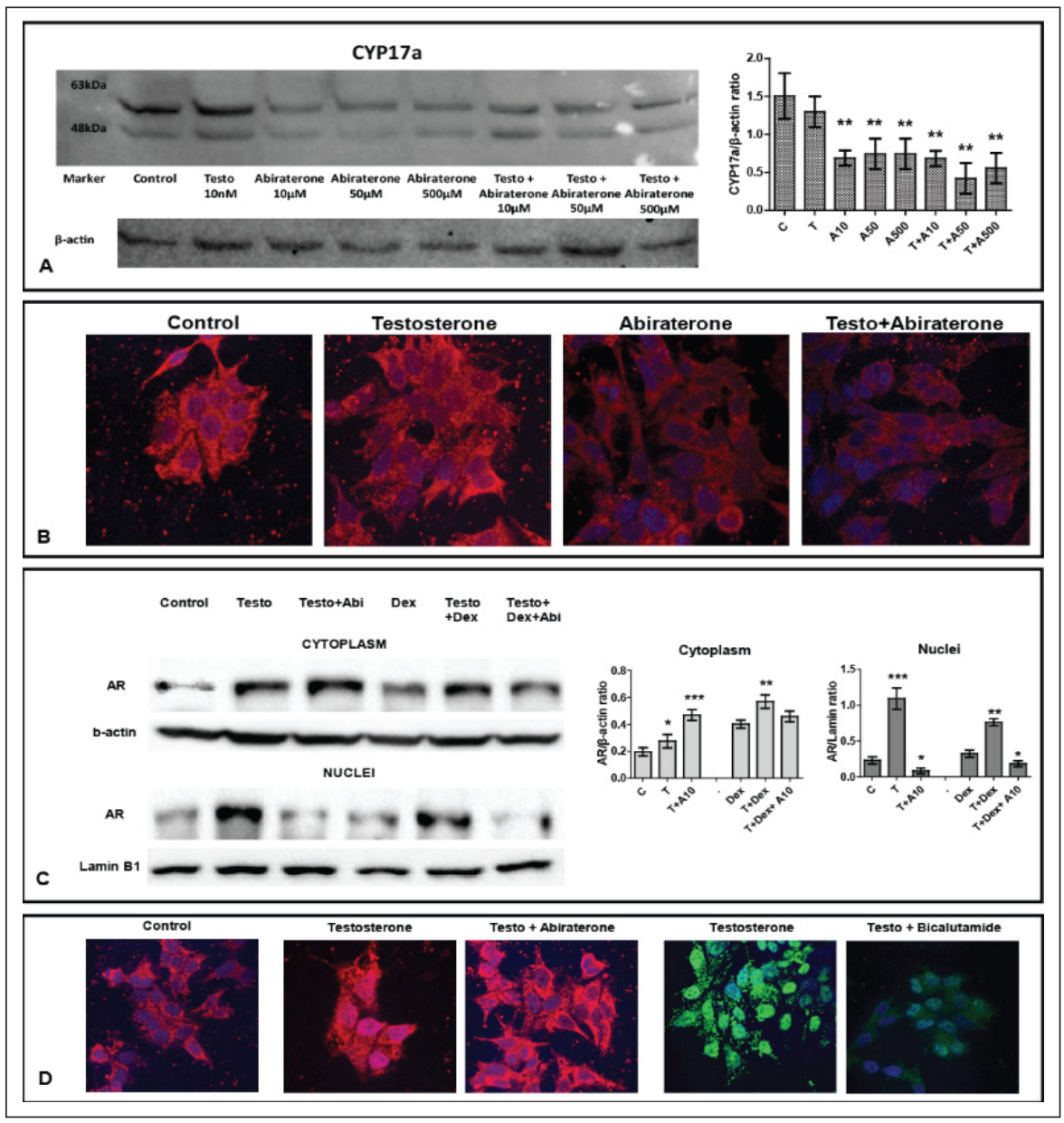

Fig. 3. A Western blot and band densitometry of CYP17A 1 expression in the 22Rv1 hormone dependent PCa cell line following $48 \mathrm{~h}$ exposure to testosterone $(10 \mathrm{nM})$ and various concentrations of abiraterone $(10,50$ and $500 \mu \mathrm{M})$; B Confocal immunofluorescent images of CYP17A expression in the 22Rv1 hormone dependent PCa cell line following $48 \mathrm{~h}$ exposure to testosterone $(10 \mathrm{nM})$, abiraterone $(10 \mu \mathrm{M})$ and combination treatment with both agents; C Western blot and band densitometry of AR expression in cytoplasm and nuclei of the 22Rv1 hormone dependent PCa cells, following $48 \mathrm{~h}$ exposure to testosterone $(10 \mathrm{nM})$, abiraterone $(10 \mu \mathrm{M})$ or dexamethazone $(20 \mu \mathrm{M})$; D Confocal immunofluorescent images of AR expression in the 22Rv1 hormone dependent PCa cell line following $48 \mathrm{~h}$ exposure to testosterone $(10 \mathrm{nM})$, abiraterone $(10 \mu \mathrm{M})$, bucalutamide $(10$ $\mu \mathrm{M})$ and combination treatment with both agents.

\section{Results}

\section{CYP17A1 and AR Expression}

Immunohistochemical analysis showed that CYP17A1 was strongly expressed in the cytoplasm of a varying percentage of PCa cells (fig. 1C, D). The expression ranged from 0 to $100 \%$ of cancer cells, median $50 \%$ among cases. Thirty cases out of $53(56.6 \%)$ expressed CYP17A1 in more than $50 \%$ of their tumor cells. Stromal fibroblasts also expressed CYP17A1 in 10/53 cases (18.8\%).
The nuclear AR expression in cancer cells ranged 0-90\% among cases (median 30\%) (fig. 1E, F). Out of 53 cases, $20(37.7 \%)$ showed expression of the AR in more than $50 \%$ of cancer cells. Stromal fibroblasts of the tumor were invariably negative.

Figure $1 \mathrm{G}$ shows the distribution of CYP17A1 and AR expression, while figure $1 \mathrm{H}$ shows the linear regression analysis between CYP17A1 and AR expression. A strong significant direct association was noted $(\mathrm{p}<0.0001, \mathrm{r}$ $=0.51)$. This was also confirmed in confocal immuno- 


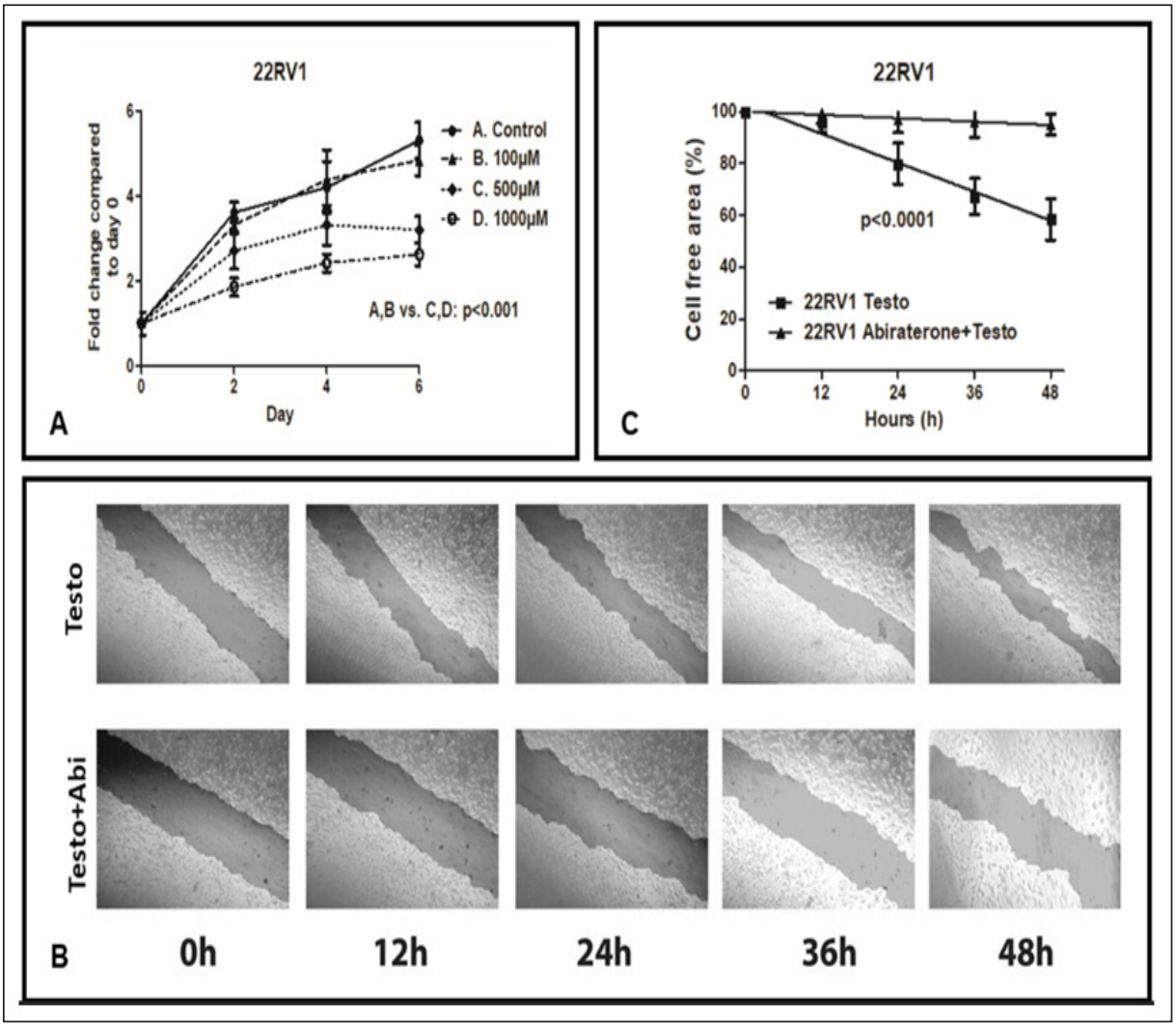

Fig. 4. A Proliferation of the $22 \mathrm{Rv} 1$ hormone dependent PCa cells under various concentrations of abiraterone $(100,500$ and $1000 \mu \mathrm{M})$; B IBIDI Single Culture-Insert images of 22RV1 PCa cell line, showing the cell free area in time (cell migration after exposure to testosterone $10 \mathrm{nM}$ with or without abiraterone $10 \mu \mathrm{M}$ ); C Graphic representation of the cell free area in the IBIDI Single Culture-Insert assay.

fluorescent microscopy, where the nuclear expression of phosphorylated (active form) of AR was directly related with cytoplasmic expression of CYP17A1 (fig. 1I).

Analysis of CYP17A1 expression according to other histopathological variables did not show any association with T-stage, Gleason score or prostate specific antigen levels.

\section{CYP17A1 and AR Expression in Cancer Cell Lines}

The expression of CYP17A1 was assessed in 3 cancer cell lines: the hormone dependent 22RV1 and the hormone independent PC3 and DU145. Western blot and band densitometry analysis showed CYP17A1 was expressed by the 22RV1 cells, while the expression in the hormone independent PC3 and DU145 was very low ( $p<0.0001$; fig. 2A, B). This was also confirmed at the mRNA level in RT-PCR analysis ( $p<0.0001$; fig. 2 ) .
AR protein and mRNA expression was evident in the 22RV1, while poor expression was noted in the PC3 and DU145 cell lines, both in western blot and RT-PCR analysis (fig. 2A, B, C).

Effect of Testosterone and Abiraterone on 22Rv1 Expression Patterns

The effect of testosterone and of the CYP17A1-inhibitor abiraterone on CYP17A1 protein levels, was tested on the 22Rv1 cells using western blot and confocal microscopy. No change of CYP17A1 expression was noted after exposure to testosterone, while a marked significant reduction was evident after exposure to abiraterone, in presence or in absence of testosterone (fig. 3A, B).

Testosterone induced the expression of AR in the cytoplasm and nuclei of $22 \mathrm{Rv} 1$ cells. Abiraterone at $10 \mu \mathrm{M}$ significantly reduced the AR expression in the nuclei 
but had no effect in the cytoplasm. Dexamethasone also induced the AR expression in the nuclei and this effect was abolished by abiraterone (fig. 3C). Figure 3D shows confocal immunofluorescent images of AR expression in the 22Rv1 hormone dependent PCa cell line following $48 \mathrm{~h}$ exposure to testosterone $(10 \mathrm{nM})$ and abiraterone $(10 \mu \mathrm{M})$. The effect of bicalutamide $(10 \mu \mathrm{M})$ on AR expression is used as a control.

Effect of Abiraterone on 22Rv1 Cancer Cell Line Proliferation and Migration

Abiraterone reduced the growth rate of $22 \mathrm{Rv} 1$ cells, an effect that was dose dependent (fig. 4A). In the migration assay, abiraterone also suppressed the migration ability of the $22 \mathrm{Rv} 1$ cells, in presence of testosterone (fig. 4B, C).

\section{Discussion}

CYP17A1 is a multifunctional, hydroxylase type enzyme of cytochrome p450 family, expressed in the endoplasmic reticulum of testicular Leydig cells and the adrenal cortex. It possesses both $17 \alpha$-hydroxylase activity and 17,20-lyase activity. The hydroxylase activity is involved in glucocorticoid synthesis, while both hydroxylase and lyase activities are required in the sex hormone synthesis pathway [9].

In 2012, Mostaghel et al. [10] studied a xenograft model with the hormone sensitive LNCaP PCa tumor and reported that CYP17A1 expression by cancer cells was directly linked with intratumoral testosterone levels and also with the circulating cholesterol levels, implying that cancer cells were able to make a de novo synthesis of androgens from cholesterol. PCa xenografts growing in mice, show rapid up-regulation of CYP17A1 1 day after castration [11]. Expression of CYP17A1 may therefore provide an advantage for $\mathrm{PCa}$ cells to synthesize androgens intracellularly, bypassing the therapeutic blockage of extra-prostatic androgen sources. The current study provides evidence that CYP17A1 is strongly expressed in more than $50 \%$ of human prostate carcinomas. The extent of expression was directly linked with nuclear expression of the phosphorylated active form of ARs. Along with our data is a study by Sakai et al. [12], where CYP17A1 mRNA overexpression was found in $59 \%$ of human PCa specimens. The above findings support the hypothesis that CYP17A1 mediates intracellular synthesis of androgens that following binding to the ARs, enters the nuclei allowing AR transcriptional activity. Interestingly, the 22RV1 cell line expressing AR also expressed CYP17A1, whilst the PC3 and DU145 ones that have poor levels of AR also bore low expression of CYP17A1.

We further assessed the effect of testosterone and of abiraterone on CYP17A1 and AR levels in the hormone sensitive 22Rv1 PCa cell line. Abiraterone (CB7598) is a selective, potent and irreversible inhibitor of CYP17A1 [13]. In clinical trials, abiraterone acetate CB7630 (a prodrug deacetylated in vivo to the active CB7598 form) offered an improved overall survival in castration resistant PCa patients and was approved by the FDA for the treatment of metastatic PCa patients who had failed the docetaxel/prednisone treatment [14].

In our study, testosterone was as expected induced AR translocation to the nuclei, but no effect was noted on the CYP17A1 expression levels. Abiraterone significantly reduced the steady state AR levels in the nuclei. Of interest, abiraterone counteracted the testosterone and dexamethasone induced translocation of AR to the nuclei. This finding shows that aside to the inhibitory effect on androgen synthesis, abiraterone interferes the cytoplasmic/nuclear kinetics of ARs. Indeed in a study by Richards et al. [15], abiraterone was shown to directly bind and inhibit wild type and mutant ARs.

It is suggested that CYP17A1 steroidogenic enzyme is strongly expressed in half about of human prostate carcinomas, implying an intracellular androgen synthesis by cancer cells. A limitation of the study is the lack of data regarding biochemical relapse free survival of patients, in order to test the value of CYP17A as a prognostic marker. Abiraterone, a clinically approved CYP17A1 inhibitor, effectively blocked nuclear accumulation of AR. Whether the concentration of the drug achieved clinically, using the standard recommended dosages, are adequate to produce this effect is a question that demands in vivo studies. Whether CYP17A1 can function as a biomarker to select the best hormonal agent, amongst the several new compounds that recently became available, is a question that demands further investigation.

\section{Acknowledgement}

The study has been financially supported by the Tumour and Angiogenesis Research Group. 


\section{References}

1 Siegel RL, Miller KD, Jemal A: Cancer Statistics, 2017. CA Cancer J Clin 2017;67:7-30.

2 Cornford P, Bellmunt J, Bolla M, Briers E, De Santis M, Gross T, Henry AM, Joniau S, Lam TB, Mason MD, van der Poel HG, van der Kwast TH, Rouvière O, Wiegel T, Mottet $\mathrm{N}$ : EAU-ESTRO-SIOG guidelines on prostate cancer. Part II: Treatment of relapsing, metastatic, and castration-resistant prostate cancer. Eur Urol 2017;71:630-642.

3 Labrie F, Cusan L, Gomez JL, Martel C, Bérubé R, Bélanger P, Bélanger A, Vandenput L, Mellström D, Ohlsson C: Comparable amounts of sex steroids are made outside the gonads in men and women: strong lesson for hormone therapy of prostate and breast cancer. J Steroid Biochem Mol Biol 2009; 113:52-56.

4 Rau KM, Kang HY, Cha TL, Miller SA, Hung MC: The mechanisms and managements of hormone-therapy resistance in breast and prostate cancers. Endocr Relat Cancer 2005; $12: 511-532$.

5 Attard G, Cooper CS, de Bono JS: Steroid hormone receptors in prostate cancer: a hard habit to break? Cancer Cell 2009;16:458-462.
6 Locke JA, Guns ES, Lubik AA, Adomat HH, Hendy SC, Wood CA, Ettinger SL, Gleave ME, Nelson CC: Androgen levels increase by intratumoral de novo steroidogenesis during progression of castration-resistant prostate cancer. Cancer Res 2008;68:6407-6415.

7 Schwartz MF, Kolodny RC, Masters WH: Plasma testosterone levels of sexually functional and dysfunctional men. Arch Sex Behav 1980;9:355-366.

8 Goldberg T, Berrios-Colon E: Abiraterone (zytiga), a novel agent for the management of castration-resistant prostate cancer. P T 2013; 38:23-26.

9 Auchus RJ: Overview of dehydroepiandrosterone biosynthesis. Sem Reprod Med 2004; 22:281-288.

10 Mostaghel EA, Solomon KR, Pelton K, Freeman MR, Montgomery RB: Impact of circulating cholesterol levels on growth and intratumoral androgen concentration of prostate tumors. PLoS One 2012;7:e30062.

11 Knuuttila M, Yatkin E, Kallio J, Savolainen S, Laajala TD, Aittokallio T, Oksala R, Häkkinen M, Keski-Rahkonen P, Auriola S, Poutanen M, Mäkelä S: Castration induces up-regulation of intratumoral androgen biosynthesis and androgen receptor expression in an orthotopic $\mathrm{VCaP}$ human prostate cancer xenograft model. Am J Pathol 2014;184: 2163-2173.
12 Sakai M, Martinez-Arguelles DB, Aprikian AG, MaglioccoAM, Papadopoulos V: De novo steroid biosynthesis in human prostate cell lines and biopsies. Prostate 2016;76:575-587.

13 Barrie SE, Potter GA, Goddard PM, Haynes BP, Dowsett M, Jarman M: Pharmacology of novel steroidal inhibitors of cytochrome $\mathrm{P} 450$ (17) alpha (17 alpha-hydroxylase/C1720 lyase). J Steroid Biochem Mol Biol 1994; 50:267-273.

14 de Bono JS, Logothetis CJ, Molina A, Fizazi K, North S, Chu L, Chi KN, Jones RJ, Goodman OB Jr, Saad F, Staffurth JN, Mainwaring P, Harland S, Flaig TW, Hutson TE, Cheng T, Patterson H, Hainsworth JD, Ryan CJ, Sternberg CN, Ellard SL, Fléchon A, Saleh M, Scholz M, Efstathiou E, Zivi A, Bianchini D, Loriot Y, Chieffo N, Kheoh T, Haqq CM, Scher HI: Abiraterone and increased survival in metastatic prostate cancer. N Engl J Med 2011;364:1995-2005.

15 Richards J, Lim AC, Hay CW, Taylor AE, Wingate A, Nowakowska K, Pezaro C, Carreira S, Goodall J, Arlt W, McEwan IJ, de Bono JS, Attard G: Interactions of abiraterone, eplerenone, and prednisolone with wild-type and mutant androgen receptor: a rationale for increasing abiraterone exposure or combining with MDV3100. Cancer Res 2012;72:2176-2182. 